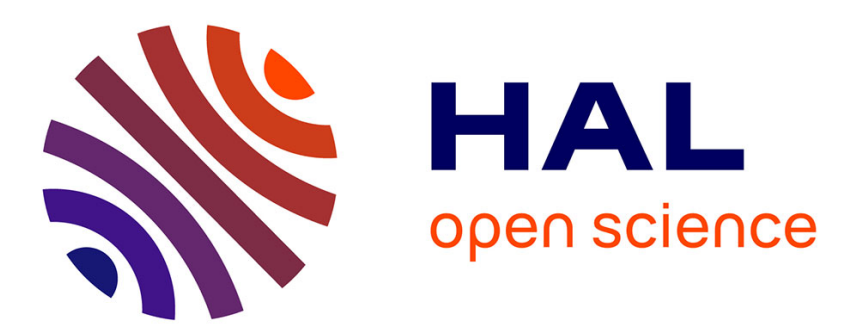

\title{
Legacy Writing and the Consumption of Biographic Services
}

\author{
Samuel Guillemot, Bertrand Urien
}

\section{To cite this version:}

Samuel Guillemot, Bertrand Urien. Legacy Writing and the Consumption of Biographic Services.

Psychology \& Marketing, 2016, 33 (11), pp.971-981. 10.1002/mar.20931 . hal-02466648

\section{HAL Id: hal-02466648 \\ https://hal.univ-brest.fr/hal-02466648}

Submitted on 9 Apr 2021

HAL is a multi-disciplinary open access archive for the deposit and dissemination of scientific research documents, whether they are published or not. The documents may come from teaching and research institutions in France or abroad, or from public or private research centers.
L'archive ouverte pluridisciplinaire HAL, est destinée au dépôt et à la diffusion de documents scientifiques de niveau recherche, publiés ou non, émanant des établissements d'enseignement et de recherche français ou étrangers, des laboratoires publics ou privés. 
HTTPS://DOI.ORG/10.1002/MAR.20931

\title{
Legacy writing and the consumption of biographic services
}

\author{
Samuel GUILLEMOT, Univ Brest, LEGO, Quimper, France \\ Bertrand URIEN, Univ Brest, LEGO, Brest, France
}

\begin{abstract}
This study focuses on legacy writing and the development of the life-history business (e.g. family ghostwriters and writing workshops). A theoretical model is proposed to study the underlying mental processes that lead the elderly to consume such services. This model was empirically tested on a sample of 392 individuals aged from 60 to 92 years. Results highlighted the following: the role of generativity and death preparation reminiscence on identity preservation issues in later life, the strong desire to contribute to collective memories (i.e., to reach people outside of the family circle), and the social nature of the consumption of services that could be considered as a means to share emotions. The results of this study will lead to a more in-depth understanding of consumer behavior regarding the transmission and preservation of the self at end of life, and may also help service providers to improve their products and services.
\end{abstract}

Keywords: Identity - Preservation and Transmission - Generativity - Reminiscence

TO CITE: GUILLEMOT S. AND URIEN B. (2016), LEGACY WRITING AND THE CONSUMPTION OF BIOGRAPHIC SERVICES, PSYCHOLOGY AND MARKETING, 33 (11), 971-981

The more individuals age, the more they are confronted with traumatic events that will, sooner or later, threaten their identity. These events may be both objective (e.g. loss of loved ones, deterioration of physical capabilities) and subjective (e.g. feelings of vulnerability, shortening of the limited time horizon view). When faced with these immediate or forthcoming identity upheavals, the elderly may be tempted to preserve this identity and/or to transmit it to future generations. Consumer research shows that common strategies include taking on the role of caregiver to ensure inter-generational cohesion, or that of grandparent to transmit family history and heritage (Schewe \& Balazs, 1992), using symbolic rituals (Bonsu \& Belk, 2003), and/or transmitting possessions (Curasi, 2006; Price, Arnould \& Curasi, 2000; Wallendorf \& Arnould, 1988).

Legacy writing has experienced a boom since the above-mentioned studies were published. The fragmentation of traditional family ties, the geographic dispersion of generations within a family, solitude, and the isolation inherent in modern lifestyles all contribute to the weakening of lineage links (Argentin, 2006) and may explain the emergence of legacy writing motives. As mentioned by Hunter and Rowles (2005), "the extremely mobile nature of contemporary society is leading to a greater need for attachment in some way to the places and events of our past (Relph, 1976). This perhaps explains the upsurge of autobiographical writing, concern with life histories (...). This may not have been so important in previous generations because of the strength of oral traditions transmitted within geographically proximate families, but it certainly seems to have great contemporary significance".

The personal historian, or family history ghostwriter, has developed into a veritable lifehistory business that makes it easier for individuals to transmit their life story. The emergence of these biography services has been praised in some sectors. For example, in the media, the preservation of memories was recently noted by several newspapers (including the Washington Business Journal, The Wall Street Journal and The New York Times) as a profitable business 
opportunity; in the marketing industry, Legacy Multimedia of Houston was awarded the 2012 AMCP Videographer Award of Distinction for its videotape service; and from a public policy/association perspective, some Alzheimer's groups encourage people in the early stages of the disease to make an oral recording of their memories while they still can.

Through studying legacy writing, the aim of this paper is to gain insight into identity issues, in particular the transmission and preservation of the self in later life. It will examine the motivations behind legacy writing, the origins of these motivations, and the nature and impact of different legacy writing motivations on the consumption of biographical services. The study is organized as follows. Based on an interdisciplinary literature review, the various concepts and theoretical dimensions will be linked by determining identity issues in later life and the underlying motivations behind creating a life story. In this respect, the study shows how these legacy-writing motivations can be combined expressions of more profound concepts such as life review and generativity. This theoretical background allowed us to develop several hypotheses on how motivations and their antecedents influence legacy-writing behavior and desire to use biographic services. These hypotheses were tested via a quantitative survey conducted on 392 people aged between 60 and 92 years, the results of which will be discussed considering theoretical and managerial implications. Finally, study limitations will be described and avenues of future research suggested.

\section{TRANSMISSION AND PRESERVATION OF THE SELF AT END OF LIFE}

Legacy writing, whether it be filmed, recorded, or written, reflects the research conducted on the transmission and preservation of the self at end of life, and an overview of these studies will enable the important issues to be highlighted.

\section{Special "possessions", extended self-paradigm}

The identity paradigm used in studies on preservation and transmission of the self makes a distinction between the core- and the extended-self (Belk, 1988). In this framework, several authors have highlighted the strategies that elderly individuals use to preserve their identity through "solidification of identity" (Belk, 1988; Unruh 1983) and placing symbolic value on "special" possessions, thus considering these objects as an extension of their personality (Curasi, 2006; Curasi, Price \& Arnould, 2004; Price, Arnould \& Curasi 2000; Wallendorf \& Arnould, 1988). Therefore, the transmission of these objects corresponds to several motivations such as "enacting a kin-keeping role" (the person responsible for preserving family cohesion), or "achieving symbolic immortality". Special objects have various meanings at the end of life: the valuable object of recognition (e.g. a trophy symbolizing a reasonably successful athletic "career") enables the recollection of life moments and of particular events experienced in the past (e.g. a ring or a piece of jewelry symbolizing a particular relationship). When this object is offered as a present or a legacy to someone who will know how to preserve its meaning, for the giver, this is a way of being remembered (Price, Arnould \& Curasi, 2000). It also enables the transmission of individual and family values and is a vehicle for intergenerational transmission (Goldberg, 2009). Furthermore, it has a therapeutic value and, in particular, serves as a point of anchorage and stability (Wapner, Demick \& Redondo, 1990). 
Transmission and preservation of the self through self-extensions raises the issue of the loss of meaning that is linked with these objects. Price et al (2000) state that deciding to part with an object in which we have invested a part of our identity stems from a complex thought process that associates the notion of finality, the meaning associated with the object, and the relationship with the object's recipient.

\section{Legacy writing, "narrative identity paradigm"}

Since Belk (1988), one of the major developments in consumer research on identity has been on the structuring of the consumer's sense of identity in the form of a narrative (Escalas \& Bettman, 2000; Fournier, 1998; Giddens, 1991; Thompson, 1996, 1997; Thompson \& Tambyah, 1999). According to Ahuvia (2005), "since the publication of Belk (1988), narrative theory, in which our sense of identity is structured as a story, has emerged as the dominant conceptualization of the self. This means that in addition to seeing one's identity as a list of attributes [...] these attributes are linked in memory to key episodes in one's life, which in turn are strung together to form a story". For McAdams "the only conceivable form for a unified and purposeful telling of an individual life is a story" (McAdams, 1996), particularly when considering the problems of selfhood under the conditions of modernity and postmodernity (McAdams, 2001). Therefore, it is not surprising to note that "the growing popularity of keeping journals, diaries and other autobiographical devices neatly parallel[s] the rise of modernity in the West (Giddens, 1991), for making sense of the modern self as it changes over time centrally involves the construction of self-narratives" (ibid).

As a result, if we take into account the "narrative self" identity paradigm, the preservation and transmission of identity may correspond to the writing and transmitting of a life story. Consequently, a deeper understanding of legacy writing behavior could lead to more in-depth knowledge about the identity issues experienced at the end of life.

\section{THE DIFFERENT TYPES OF LEGACY WRITING MOTIVATIONS}

Theoretical research indicates that legacy writing could be a means of putting the past into perspective, of rediscovering its original meaning, and of providing the "official version" of the story. A review of the multidisciplinary literature (sociological, psycho-sociological, gerontological, and autobiographical) on the subject allowed us to identify several underlying motivations for writing a life story. These motives can be considered to be either communal or agentic. Bakan (1966) states that communal refers to friendship, love, and caring for others, whereas agency refers to self-mastery, status, and victory. After a detailed description of each of these motivations, we will consider them in light of the motivations behind the transmission of special objects.

\section{Agentic motivations of legacy writing}

In the autobiographical literature, the quest for recognition is described as one of the pillars of personal writing, providing the narrator with an opportunity to focus the account on personal history (May, 1979). First, the life history can give individuals the opportunity to express what has value in their life and to depict themselves in situations they feel proud of, such as a diploma, a career, a sporting achievement, or a life path (Hubier, 2003). Therefore, the life story enables an 
individual's knowledge, skills, and accomplishments to be identified (Rubinstein, 2002). The motive can be explicitly posthumous and the role of the story is to survive the author (Zarca, 2009). The life story enables the narrator to ensure that he/she will not be forgotten after death and to communicate what he/she would like to be remembered for (Caradec, 2004). After death, there are no more opportunities to negotiate a new identity (Bonsu \& Belk, 2003). In this sense, elderly people tend to present themselves as they would like to be remembered (Unruh, 1983) and as the hero of a complete and unique life (Tarman, 1988), for example.

In addition, the literature highlights the liberating power of writing an account as it allows the narrator to express what has long been suppressed and serves as an outlet for malaise. In his time, Rousseau was one of the first illuminati to use his confessions to justify his conduct. Thus, the desire to confess, to give one's version of the facts, can be a driving force behind legacy writing. Similarly, the life story provides an opportunity to defend oneself against accusations deemed unfounded, to give one's version of the facts, to correct, or to deny (Lejeune, 2005).

\section{Communal motivations of legacy writing}

Legacy writing is not only about the narrator, it is also a way of communication; recalling lived experiences can be a form of socialization similar to social networking. Elderly people age with a disappearing world in mind and are, hence, the protectors of our collective identity. Therefore, it is the desire to transmit, demonstrate and share that shapes many life stories (Milion-Lajoinie, 1999). Two levels of communal motivations can be put forward: family and collective.

Family communal motivations refer to the need to transmit something before it disappears because finiteness is a menace to family memory. In this sense, the writing of a life story is described as a means of transmission enabling people to "pass on the baton" to younger members of a family or a community (Martin-Sanchez, 2003). Legacy writing is a support for individual memory, but also for family, collective, and transgenerational memory (Gucher, 2009). Writing a life story is a way of remembering those who have died and of making their identity known to the younger generation (Zanone, 2006).

Collective communal motivations refer to the life story as a means of representing collective destiny because the narrator can recount witnessed or experienced events. The desire to bear witness shapes many life stories and as such, individual biographies become sources for tomorrow's sociologists, historians, or other researchers (Fabre, 2002; Lejeune, 2005; Lyons, 2001).

Considering that each type of motivation supposedly influences legacy writing behavior, we have formulated the following series of hypotheses:

$\mathrm{H}_{1}$ : Agentic legacy writing motivations have a positive influence on writing behavior

$\mathrm{H}_{2 \mathrm{a}}$ : Family communal legacy writing motivations have a positive influence on writing behavior

$\mathrm{H}_{2 \mathrm{~b}}$ : Collective communal legacy writing motivations have a positive influence on writing behavior 
Additionally, we wish to gain further insight into the consumption of biographic services, which range from step-by-step guides (books or software) for writing/recording chapter one of the life story to the Autobiography/Memoir Class(room). Many previous studies have examined the role of behavioral intentions in predicting actual behavior and this previous research is primarily based on the Theory of Reasoned Action developed by Ajzen and Fishbein (1980). By considering the meta-analyses available on the intention-behavior relationship (Hale, Householder \& Greene, 2002), the theory of reasoned action suggests that behavioral intentions are a good indicator of actual behavior. Therefore, the following hypothesis can be put forward:

$\mathrm{H}_{3}$ : An individual engaged in a writing behavior has a positive intent to use biographic services

\section{ANTECEDENTS OF THE LEGACY WRITING PROCESS}

\section{The key role of the "final life review" and reminiscence}

Price et al (2000) use life review theories to explain "preservation" and "transmission of the self" behaviors. Life review is a normative process that all people undergo when they realize their life is coming to an end (Butler, 1963) and implies a search for meaning through reflection on one's life experience (Coleman, 2005).

While life review or reminiscence are not age specific, some authors refer to a "final life review". This is the use of one's past to prepare for and come to terms with the idea of death (death preparation reminiscence - Webster, 1997). Indeed, when end of life is approaching, individuals conduct a final "review" (McAdams, 2001); the "story" is coming to its end and people become historians of their own life. There is the need to explain things, recall personal stories constructed throughout life, and establish the official account of one's life as a sort of anthology of the self. In retirement homes, geriatricians and other relevant specialists note that many elderly individuals are committed, to varying degrees, to the structuring of a coherent life story that they "write in their head" (Argentin, 2006; Freyssenet, 1995; de Givenchy, 2004; Lalive d'Epinay, 2009). For McAdams, "the construction of coherent life stories is an especially challenging problem for adults living in contemporary modern and postmodern societies, wherein selves are viewed as reflexive projects imbued with complexity and depth, ever-changing and yet demanding a coherent framing". It is precisely this "final" life story that would allow individuals to find meaning and unity where Gergen (1992) sees only multiple selves and fractured stories.

The final life review process is a form of reminiscence that is easier for people who tend to use their memory to establish and clarify important dimensions of their personality, and who use memories to come to terms with the proximity of death and existential questions on end of life (death preparation reminiscence, Webster, 2003). It is reasonable to think that these functions could cultivate different motives. Since identity is negotiated by ante mortem experiences (Bonsu $\&$ Belk, 2003), the following hypothesis $\left(\mathrm{H}_{4}\right)$ can be put forward:

$\mathrm{H}_{4 a}$ : Death preparation reminiscence has a positive influence on agentic legacy writing motivations 
$\mathrm{H}_{4 \mathrm{~b}}$ : Death preparation reminiscence has a positive influence on family communal legacy writing motivations

$\mathrm{H}_{4 c}$ : Death preparation reminiscence has a positive influence on collective communal legacy writing motivations

\section{The importance of generativity}

The concept of generativity was first introduced over 50 years ago by Erik Erikson (1959) in his theory of the human life cycle. This theory of human development contains eight stages of human life, of which "generativity versus stagnation" is the seventh. One of the first experiences of generativity may be expressed through child-bearing and -rearing. However, a broader view of this concept includes different life settings such as the proclivity to volunteer and participate in community activities (McAdams \& de St. Aubin, 1998). According to Erikson, Kotre (1999) defined generativity as the desire to live in such a way so that what is created will outlive one's own life. For McAdams, Hart and Maruna (1998), the concept of generativity consists of the following seven elements: "constellation of inner desire, cultural demand, conscious concern, belief, commitment, action and narration revolving around and ultimately justified in terms of the overall psychological goal of providing for the survival, well-being and development of human life in succeeding generations" (p. 9). More specifically, based on Bakan (1966), McAdams considers there to be two inner desires that form the foundation of generativity: communal desires and agentic desires, the characteristics of which have been described above.

Erikson's (1959) original conception of generativity suggests that it is embedded in the last stages of life and as such, appertains to older individuals. However, Kotre (1999) expanded the concept and freed it from a fixed chronological position. For Kotre, Erikson does not distinguish between different types of generativity and different aspects of generativity may come and go over the life course. Thus, "societal generativity", which is characterized by caring for younger adults, serving as a mentor, and generally contributing to the continuity of subsequent generations, begins around midlife and remains predominant until late adulthood (Schoklitsch \& Baumann, 2012). Vaillant (2002) extended this: in his theory of adult development he introduces an intermediate stage between generativity (vs stagnation) and integrity (vs despair). It is the "keeper of the meaning" stage when focus is placed on the conservation and preservation of collective products and, consequently, on culture and institutions rather than on child development. Hunter and Rowles (2005) refer to "cultural generativity" as a "vehicle that carries the meaning of life from one generation to another". Thus, faced with the end of one's existence, aging individuals will call upon their memories in a final life review process and will construct "a generative script $[. .$.$] to leave a legacy of the self to the next generation" (McAdams \& de St$ Aubin, 1992). "The generativity script functions to address the narrative need for the sense of an ending" (ibid). This is why Schoklitsch \& Baumann (2012) considered narration to be especially important in old age. For McAdams \& de St Aubin (1998, p 9): “A person's life story can itself be a kind of generative legacy, for the story itself is psychosocially created and maintained and sometimes offered to others (e.g. one's children or others who may benefit from knowing about one's life) as a lesson or gift".

As such, even though the autobiography relates to a generative action, it is derived from a generative commitment (corresponding to certain legacy writing motives) underpinned by a generative interest which has future generations in mind (McAdams, Holly \& Maruna, 1998). 
Recent research in this field identifies several generative interest dimensions (Urien \& Kilbourne 2011), two of which seem to be antecedents to the legacy writing motives of passing on and posterity:

"Passing on" deals with the transmission of skills or know-how to the next generation and, therefore, it seems legitimate to formulate the following hypothesis $\left(\mathrm{H}_{5}\right)$ :

$\mathrm{H}_{5 \mathrm{a}}$ : an individual's interest in transmitting elements (know-how, etc.) to future generations (the passing on component of generative interest) has a positive influence on family communal legacy writing motivations

$\mathrm{H}_{5 \mathrm{~b}}$ : an individual's interest in transmitting elements (know-how, etc.) to future generations (the passing on component of generative interest) has a positive influence on collective communal legacy writing motivations

"Posterity" relates to the posthumous memory of the self. In this case it may be linked to agentic motives (flattering and mending the ego, being remembered) by using a form of the relatively obscure generativity identified by Kotre \& Kotre (1998). This results in egocentric behaviors in which the individual considers him/herself to be a model, or which manifest themselves in forms of rejection or denunciation. From this, the following hypothesis $\left(\mathrm{H}_{6}\right)$ can be suggested:

$\mathrm{H}_{6}$ : an individual's interest in being remembered by future generations (the posterity component of generative interest) has a positive influence on agentic legacy writing motivations

\section{HYPOTHESIS TESTING}

The model that is to be tested takes into account all of the hypotheses, which range from related legacy writing antecedents to motivations, and up to behavioral intentions. In this section, we empirically test the model.

\section{Measurement}

This study used measuring tools that had previously been tested and validated. A part of the legacy writing motivations scale designed intentionally for an aging population (Guillemot \& Urien, 2010) was used. The original scale is composed of 20 items divided into six dimensions representing different legacy writing motivations. We used 12 items of the original scale for the present study: six representing the agentic motivation (labeled flattering and mending the ego in the original scale) and six for communal motivations (labeled transmitting and bearing witness)

To measure the final life review process, the death preparation reminiscence dimension of the Reminiscence Functions Scale (RFS - Webster, 1997) was used.

The "posterity" and "passing on" dimensions of generative interest were studied using the Loyola Generative Scale (LGS - McAdams \& de St Aubin, 1992) - adapted by Urien and Kilbourne (2011) and composed of three items for each of the two dimensions. 
We then defined three items to represent legacy writing behavior as described in the literature: writing a memoir/autobiography, writing down memories, or writing a personal diary. The various types of responses represent a degree of growing commitment in writing behavior that range from "not interested" to "already involved in the writing process". The latter relates to the writing process itself, whether it is in progress or finished. Although the scale is not metric, the data may be estimated in a structural equations model as the modalities reflect a degree of growing commitment (Byrne, 2006). In such a case, estimation by the maximum-likelihood procedure with the Satorra and Bentler (1988) corrected coefficients of significance guarantees reliable results (DiStephano, 2002).

Finally, the intent to consume biographic services was operationalized using item measurements representing the most well-known learning (writing workshop, methodological workshop) and co-production (private biographer) services. All items used a 5-point Likert scale ( 1 = strongly disagree, $5=$ strongly agree) and a 4-point rating scale for intent to consume. The final list of items is presented in appendix 1.

\section{Data Collection}

Data were collected in France by self-administered questionnaires. France is representative of Western countries in terms of population aging. According to the French National Institute of Statistics and Economic Studies (Insee), the over-60 age group currently represents $23 \%$ of the population and should account for over one third of the population in 2060 (Blanpain \& Chardon, 2010). Before proceeding to the data collection process, it was necessary to ensure measurement scale stability in a French cultural context. This phase had already been carried out for the scales of legacy writing motivations and for generativity, and the same process was adopted for the reminiscence scale. Previously, this scale had been translated into French according to the "backtranslation" method and submitted to a sample of 169 persons aged 60 years and over. Treatment of data via exploratory and confirmatory factorial analyses indicated a stable structure by retaining seven items (four for the "identity" dimension and three for "death preparation"). Eliminating some items does not alter the nature of the structure as this is a reflexive measure indicator.

The final data collection contained 392 responses (table 1). The questionnaires were presented as being based on a "memories" theme and were distributed (with a stamped addressed envelope enclosed) in potential meeting places for retired persons: universities of the third age, associations, offices and pensioners' clubs. A return rate of over $42 \%$ was recorded, thus illustrating peoples' interest in the subject.

Table 1. Summary profile of informants

\begin{tabular}{|c|c|c|c|c|c|}
\hline \multicolumn{2}{|l|}{ Gender } & \multicolumn{2}{|l|}{ Age } & \multicolumn{2}{|l|}{ Family } \\
\hline Female & 251 & Age range & $60-94$ & No children & 45 \\
\hline Male & 141 & Average age & 68.40 & Children, no grandchildren & 75 \\
\hline & & & & Children and grandchildren & 272 \\
\hline
\end{tabular}




\section{Validation of the Measurement Instrument}

The objective of this section is to validate the measurement instrument using a confirmatory factor analysis, as per the procedure of Anderson and Gerbing (1988) and the structural equations method (EQS 6.1 software). Jöreskog's rhô coherence coefficients $(\rho)$ are always superior to 0.7 (Table 2) - a threshold which is commonly accepted as ensuring the reliability of measuring instruments (Fornell \& Larker, 1981). Next, the convergent validity was verified when the links between the latent variable and its indicators were significant and when each indicator shared more variance with its construct than with its associated error term (Steenkamp \& Van Trijp, 1991). These conditions are concretely filled if the $\mathrm{z}$ test associated to each of the factorial contributions is > 1.96 and when the average variance extracted (AVE) for each dimension is > 0.5 . This is the case here (Table 2).

Table 2. Convergent Validity Testing

\begin{tabular}{|c|c|c|c|c|c|}
\hline Construct & Item & $\begin{array}{l}\text { Standard } \\
\text { Loading }\end{array}$ & $\mathrm{Z}$ Test Value & $\begin{array}{l}\text { Joreskog rhô } \\
(\rho)\end{array}$ & $\begin{array}{c}\text { Convergent validity } \\
\text { rhô }\left(\rho_{\mathrm{vc}}\right)\end{array}$ \\
\hline \multicolumn{6}{|c|}{ Legacy writing motivations } \\
\hline \multirow[t]{6}{*}{ Agentic motivations } & AGE1 & .75 & $>10$ & .87 & .52 \\
\hline & AGE2 & .81 & & & \\
\hline & AGE3 & .75 & & & \\
\hline & AGE4 & .55 & & & \\
\hline & AGE5 & 69 & & & \\
\hline & AGE6 & .75 & & & \\
\hline \multirow{3}{*}{$\begin{array}{l}\text { Family communal } \\
\text { motivations }\end{array}$} & FCM1 & .63 & $>11$ & .78 & .55 \\
\hline & FCM2 & .79 & & & \\
\hline & FCM3 & .79 & & & \\
\hline \multirow{3}{*}{$\begin{array}{l}\text { Collective communal } \\
\text { motivations }\end{array}$} & CCM1 & .74 & $>11$ & .80 & .58 \\
\hline & $\mathrm{CCM} 2$ & .83 & & & \\
\hline & CCM3 & .70 & & & \\
\hline \multicolumn{6}{|c|}{ Antecedents to legacy writing motivations } \\
\hline \multirow{3}{*}{$\begin{array}{l}\text { Death Preparation } \\
\text { Reminiscence }\end{array}$} & DPR1 & .78 & $>15$ & .86 & 67 \\
\hline & DPR2 & .87 & & & \\
\hline & DPR3 & .80 & & & \\
\hline \multirow[t]{3}{*}{ Posterity Generativity } & PGE1 & .82 & $>15$ & .85 & .65 \\
\hline & PGE2 & .76 & & & \\
\hline & PGE3 & .83 & & & \\
\hline \multirow[t]{3}{*}{ Passing on Generativity } & POG1 & .78 & $>8$ & .76 & .52 \\
\hline & POG2 & .76 & & & \\
\hline & POG3 & .60 & & & \\
\hline \multicolumn{6}{|c|}{ Effects of legacy writing motivations } \\
\hline \multirow[t]{3}{*}{ Writing behavior } & WBE1 & .88 & $>7$ & .79 & .57 \\
\hline & WBE2 & .89 & & & \\
\hline & WBE3 & .39 & & & \\
\hline \multirow{3}{*}{$\begin{array}{l}\text { Desire to consume } \\
\text { biographic services }\end{array}$} & BSI1 & .93 & $>10$ & .84 & .64 \\
\hline & BSI2 & .83 & & & \\
\hline & BSI3 & 60 & & & \\
\hline
\end{tabular}


Finally, discriminant validity is also ensured since the constructs are different both theoretically and empirically. Table 3 shows that the correlations between the two constructs are less than the square root of their AVEs (diagonal term), which means that indicators of a same dimension share more variance between them than with those of other dimensions.

Table 3. Correlations between Latent Constructs

\begin{tabular}{lcccccccc}
\hline & AGE & FCM & CCM & DPR & PGE & POG & WBE & BSI \\
\hline AGE & $\mathbf{. 7 2}$ & & & & & & & \\
FCM & .45 & $\mathbf{. 7 4}$ & & & & & & \\
CCM & .49 & .66 & $\mathbf{. 7 6}$ & & & & & \\
DPR & .44 & .21 & .24 & $\mathbf{. 8 2}$ & & & & \\
PGE & .53 & .22 & .37 & .31 & $\mathbf{. 8 1}$ & & & \\
POG & .35 & .27 & .33 & .10 & .59 & $\mathbf{. 7 2}$ & & \\
WBR & .36 & .40 & .51 & .31 & .19 & .24 & $\mathbf{. 7 5}$ & \\
BSI & .40 & .39 & .39 & .37 & .27 & .22 & .48 & $\mathbf{. 8 0}$ \\
\hline
\end{tabular}

Note: AGE $=$ AGentic Motivations, FCM $=$ Family Communal Motivations, $\mathrm{CCM}=$ Collective Communal Motivations, $\mathrm{DPR}=$ Death Preparation Reminiscence, PGE = Posterity GEnerativity posterity, $\mathrm{POG}=$ Passing On Generativity, $\mathrm{WBE}=$ Writing behavior, BSI $=$ Biographic Services Intention

All significant at 5\% level

\section{RESULTS}

The fit indices of the model $\left(\chi^{2}=745 ; \mathrm{df}=309(\mathrm{p}=.00)\right.$; CFI $=.90$; RMSEA $=.062$ [.056$.067])$ are acceptable. All of the hypotheses are verified. The structural standardized coefficients are presented in figure 1.

Figure 1. Model

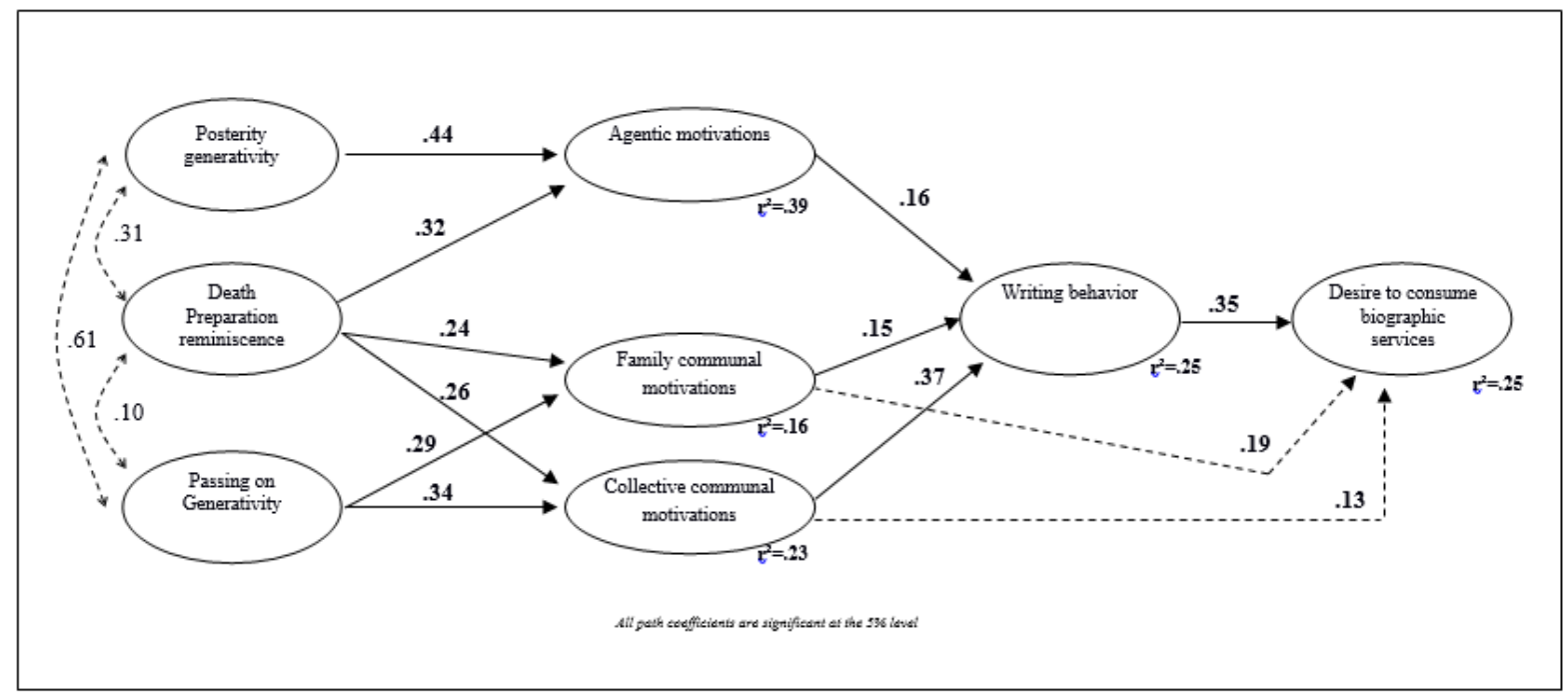


Three main conclusions can be drawn from the empirical test. Firstly, our study theoretically highlights and empirically confirms that legacy writing motives are based on the capacity for structured reminiscence to confront existential questions about end of life and on a direction towards the next generation (based on the memory that individuals will leave behind and on aspects that they wish to transmit). Together, those exogenous variables explained $39 \%$ of the variance of agentic motivations, and also $39 \%$ of communal motivations (respectively $16 \%$ and $23 \%$ for the family and collective level).

Secondly, collective communal motivations have a relatively greater impact (.37) than family communal (.15) and agentic (.16) motivations on writing behavior $\left(\mathrm{r}^{2}=.25\right)$.

Thirdly, the Lagrange test put forward significant effects that were not expected: the direct effect of both family (.19) and collective (.13) communal motivations on the desire to use biographic services $\left(\mathrm{r}^{2}=.25\right)$.

\section{DISCUSSION}

Considering the narrative self-identity paradigm, preservation and transmission of the self correspond to the preservation and transmission of one's history, and we have shown that legacy writing could complement the role held by special objects in the extended-self paradigm. The study provides further insight into the antecedents of such identity issues, the key role of collective communal motivations in legacy writing behavior and the social nature of biographic services consumption.

\section{A better understanding of the identity transmission and preservation process}

The central question is whether these new developments can benefit research on preservation and transmission of the self in end of life. This study sheds light on several new elements in this respect: it shows how (i) the motives behind the creation of a life story originate and, in particular, clarify the roles of generativity and death preparation reminiscence, and (ii) that the type of motivations behind legacy writing are communal or agentic.

From a managerial perspective, generativity and family communal motivations are already taken into account with marketing arguments such as "creating a memoir is a great way to connect generation and preserve memories". Conversely death preparation reminiscence and agentic motivations appear to be largely forgotten. However, numerous studies have shown that there are many advantages to coherently structuring one's life story. It not only has a positive influence on mood (Fallot, 1980), life satisfaction (Cook, 1998), well-being (Haight, 1988), depression (Bohlmeijer, Smith \& Cuijpers, 2003), and anxiety when facing death (Jones, Lyons \& Cunningham, 2003), but it also resolves memory problems (Hirsch \& Mourtoglou, 1999). It gives the sensation of being in control of one's life as opposed to the sense of powerlessness felt when facing the loss of reference points and identity linked to the aging process. These arguments may be used by service providers in addition to generativity-related arguments. 
The identified legacy writing motivations correspond to the motivations behind transmitting special objects at the end of life, but there is a difference between them: the collective communal motivation does not appear for special objects but it is central to the legacy writing process. Indeed, the impact of collective communal motivations on writing behavior is double the impact of agentic and family communal motivations (with reference to the empirical test). This result could be explained as follows: the act of explicitly laying out one's life story in writing makes it possible to ease the fear associated with the loss of meaning. It enables the writer to expand the circle of potential receivers, namely to people outside the family circle. A family's lack of interest can indeed be countered by the addition of other, sometimes unknown, readers who will know how to fully appreciate the meaning of the story.

Legacy writing appears to be a powerful way for individuals to satisfy their desire to contribute to collective memory. The narrator may represent a collective destiny by becoming, for example, the village historian or describing a bygone profession (Lecarme \& LecarmeTabone, 1999). Legacy writing service providers could put narrators and researchers (e.g. geographers, historians or sociologists) interested in this type of testimony in touch with one another.

\section{Consumption of services as a way of "sharing"}

We found a direct link between communal motivation and the desire to use biographic service without the intent to engage in a writing behavior. Theoretically, this result is understandable: it could be derived from a request made by grandchildren or children wishing to gather family memories, or obtain information about certain events. This result reveals the social nature of legacy writing that has proved to be a means of sharing reminiscences with family and/or peers. Biographic services then become a mean of putting emotions, feelings, images, etc. into writing.

Biographic services are valued because they provide skills and a support for the life story and above all, because they create favorable conditions for sharing and exchange. For this reason, based on Rimé's theory of the Social Sharing of Emotion (2005), we recommend that providers develop group writing workshops. Indeed, consumers may place equal value on being listened to, criticized (for the sake of improvement) and reacting to the memories of others. Elderly individuals may have things that they would like to tell future generations, but also more simply, they have things they want to tell and share with other people.

\section{LIMITATIONS AND AVENUES OF RESEARCH}

The results of the study must be interpreted by taking several limitations into account and this highlights the need for future research. One of these limitations relates to the generalization of the results. It would be worthwhile repeating the study on other populations and, in particular, in other cultural or religious contexts. Extending the research should take into account the impact of environmental factors (financial resources, free time and how it is used, etc.) and potentially moderating variables (personality traits, tendency to procrastinate, level of self-esteem or sense of self-efficacy, etc.). 
Another important limitation is the individual's relationship with death. Like in other studies on special objects, it is considered here as an axiom, as a self-evident and unquestionable fact. It would thus be interesting to test the impact of certain sub-dimensions of individuals' attitudes towards death on the behavior of legacy writing, be it on the basis, motives, or act of writing. Effectively, the fear of death (Florian \& Snowden, 1989) contains certain sub-dimensions such as the loss of personal fulfillment, self-annihilation, the loss of social identity, consequences for loves ones, transcendental consequences, or even punishment after death. These sub-dimensions could have a general impact on the preservation and transmission of the self in ways that are yet to be determined, and more specifically, on the behaviors linked to legacy writing.

In this study, we contrasted special objects with legacy writing, but should they not be understood as complementary? This question is being raised more often with the rise of digital technology. Some objects that hold meaning, such as photographs or private correspondence, now tend to only exist in digital form, which means that memories are also captured and distributed by digital possessions (e.g. digital photos) (Belk, 2013). Some services that are being developed (such as PartingWishes.com and MyWonderfulLife.com) recommend dealing with the digital legacy of e-mails, social media, and other online traces as well as declaring an executor of one's "digital estate” (Belk, 2013; Carroll \& Romano, 2011).

\section{REFERENCES}

Ahuvia, A.C. (2005). Beyond the extended self: loved objects and consumers' identity narratives. Journal of Consumer Research, 32, 171-184

Ajzen, I. \& Fishbein, M. (1980). Understanding attitudes and predicting social behavior. Englewood Cliffs, NJ : Prentice-Hall

Anderson, J.C. \& Gerbin, D.W (1988). Structural equation modeling in practice: A review and recommended two-step approach. Psychological Bulletin, 103 (3), 411-423.

Argentin, L. (2006). Parler de son temps : récits de vie et ateliers d'écritures. Soins Gérontologie, 57, 38-42.

Bakan, D. (1966). The duality of human existence: Isolation and communion in western man. Boston: Beacon Press.

Belk, R.W. (1988). Possessions and the extended self. Journal of Consumer Research, 15 (2), 139-168.

Belk, R.W. (2013). The extended self in a digital world. Journal of Consumer Research, 40 (3), 477-500.

Blanpain, N. \& Chardon, O. (2010). Projections de population 2007-2060 pour la France métropolitaine. Insee Résultats-Société, 117 (December), 1-4.

Bohlmeijer, E., Smith, F. \& Cuijpers P.I. (2003). Effects of reminiscence and life review on latelate depression: A meta-analysis. International Journal of Geriatric Psychiatry, 18 (12), 10881094.

Bonsu, S.K. \& Belk R.W. (2003). Do not go cheaply into that good night: Death ritual consumption in asante ghana. Journal of Consumer Research, 30 (1), 41-55.

Butler, R.N. (1963). The life review: An interpretation of reminiscence in the age. Psychiatry, 26, 65-75.

Byrne, B.M. (2006). Structural equation modeling with EQS: Basic concepts, applications, and programming ( $2^{\text {nd }}$ edition). Thousand Oaks, CA: Sage. 
Caradec, V. (2004). Vieillir après la retraite, approche sociologique du vieillissement. Paris: PUF

Carroll, E. \& Romano J. (2010). Your digital afterlife: When facebook, flickr and twitter are your estate, what's your legacy?. Berkeley, CA: New Rider's Press.

Coleman, P.G. (2005). Uses of reminiscence: Functions and benefits. Aging and Mental Health, 9, 291-294.

Curasi, C.F. (2006). Maybe it is your father's oldsmobile: The construction and preservation of family identity through the transfer of possessions. In C. Pechmann \& L. Price (Eds), Advances in Consumer Research (Vol. 33, p.82-86). San Antonio, TX: Association for Consumer Research.

Curasi, CF., Price, L.L \& Arnould, E.J. (2004). How individuals' cherished possessions become families' inalienable wealth. Journal of Consumer Research, 31 (3), 609-622.

Cook, E.A. (1998). Effects of reminiscence on life satisfaction of elderly female nursing home residents. Health Care for Women International, 19 (2), 109-118.

DiStefano, C. (2002). The impact of categorization with confirmatory factor analysis. Structural equation modelling: A multidisciplinary journal, 9, 327-346.

Erikson, E. (1959). Identity and the life cycle: Selected papers. Psychological Issues, 1 (1), 50100.

Escalas, J.E. \& Bettman, J.R. (2000). Using narratives to discern self-identity related consumer goals and motivations. In C. Huffman, S. Ratneshwar \& D.G. Mick (Eds.), The why of consumption: Contemporary perspectives on consumer motives, goals, and desires (pp 237258). New York: Routledge \& Kegan Paul

Fabre, D. (2002). Vivre, écrire, archiver. Sociétés et Représentations, 13 (1), 17-42.

Fallot, R.D. (1980). The impact of mood on verbal reminiscing in late adulthood. International Journal of Aging and Human Development, 10 (4), 385-400.

Florian, V. \& Snowden, L.R. (1989). Fear of personal death and positive life regard. Journal of Cross-Cultural Psychology, 20 (1), 64-79.

Fornell, C. \& Larcker, D.F. (1981). Evaluating structural equations models with unobservable variable and measurement error. Journal of Marketing Research, 18 (1), 39-50.

Fournier, S. (1998). Consumers and their brands: developing relationship theory in consumer research. Journal of Consumer Research, 24 (March), 343-373.

Freyssenet, M.G. (1995). Psychopathologie quotidienne des petits vieux. In N. Tobie (Ed.), Rituels de deuil, travail de deuil (pp.141-174). Grenoble (France) : Editions La pensée sauvage.

Gergen, K.J. (1992). The saturated self: Dilemmas of identity in contemporary life. New York: Basic Books.

Giddens, A. (1991). Modernity and self-identity, self and society in the late modern age. Stanford University Press.

de Givenchy, P. (2004). Ma vie est un vrai roman.... In J-L. Sudres, G. Roux, M. Laharie \& F. de la Fournière (Eds.), La personne âgée en art-thérapie, de l'expression au lien social (pp. 93-96). Paris, L'Harmattan.

Goldberg, A. (2009). Réaliser une boîte à souvenir. Gérontologie et Société, 130, 155-170.

Gucher, C. (2009). Vieillir en mémoire paysanne: des lieux, des liens, continuité et permanence de sens et d'usage. Gérontologie et Société, 130 (3), 107-125

Guillemot, S. \& Urien B. (2010). Legacy writing among the elderly: Conceptual bases, dimensioning and a proposed scale for measuring motivations. Recherche et Applications en Marketing, 25 (4), 25-43.

Haight, B.K. (1988). The therapeutic role of a structured life review process in homebound elderly subjects. Journal of Gerontology: Psychological Sciences, 43 (2), 40-44. 
Hale, J.L., Householder, B.J. \& Greene, K.L. (2002). The theory of reasoned action. In J-P. Dillard \& M. Pfau (Eds.), The persuasion handbook: Developments in theory and practice (pp.259-286). Thousand Oaks, CA: Sage.

Hirsch, C.R. \& Mouratoglou, V.M. (1999). Life review of an older adult with memory difficulties. International Journal of Geriatric Psychiatry, 14 (4), 261-265.

Hubier, S. (2003). Littératures intimes : Les expressions du moi, de l'autobiographie à l'autofiction. Paris : A. Colin.

Hunter, E.G. \& Rowles, G.D. (2005). Leaving a legacy: Toward a typology. Journal of Aging Studies, 19 (3), 327-347.

Jones, C., Lyons, C. \& Cunningham, C. (2003). Life review following critical illness in young men. Nursing in Critical Care, 8 (6), 256-263.

Kotre, J. (1999). Make it count: How to generate a legacy that gives meaning to your life. New York: Free Press.

Kotre, J. \& Kotre K.B. (1998). Intergenerational buffers: The damage stops here. In D.P. McAdams \& E. de St Aubin (Eds.), Generativity and adult development: How and why we care for the next generation (pp.367-390). Washington, DC: American Psychological Association.

Lalive d'Épinay, C. \& Stefano C. (2009). Mémoire de l'histoire et appartenance générationnelle des personnes âgées. Gérontologie et Société, 130, 127-144.

Lecarme, J. \& Lecarme-Tabone E. (1999). L'autobiographie. Paris : Armand Colin.

Lejeune, P (2005). Signes de vie: Le pacte autobiographique 2. Paris, Le Seuil.

Lyons, M. (2001). La culture littéraire des travailleurs, autobiographies ouvrières dans l'Europe du XIX siècle. Annales HSS, 4 (5) ; 927-946.

Martin Sanchez, M-O (2003). Discours oraux, discours écrits, les seniors et l'écriture de soi. Gérontologie et Société, 106, 97-109.

May, G. (1979). L'autobiographie. Paris : PUF.

McAdams, D.P. (1996). Personality, modernity, and the storied self: A contemporary framework for studying persons. Psychological Inquiry, 7, 4, 295-321.

McAdams, D.P. (2001). Unity and purpose in human lives: The emergence of Identity as a life story. In A.I. Rabin, R.A. Zucker, R.A. Emmuns \& S. Franck (Eds.), Studying persons and lives (pp.148-200). NY: Springer.

McAdams, D.P. \& de St. Aubin, E. (1992). A theory of generativity and its assessment through self-report, behavioural acts, and narrative themes in autobiography. Journal of Personality and Social Psychology, 62 (6), 1003-1015.

McAdams, D.P., \& de St. Aubin, E. (1998). Generativity and adult development: How and why we care for the next generation. Washington DC: American Psychological Association

McAdams, D.P., Hart, H. \& Maruna, S. (1998). The anatomy of generativity. In D.P. McAdams $\&$ E. de St Aubin (Eds.), Generativity and adult development: How and why we care for the next generation (pp.7-44). Washington DC, American Psychological Association.

Million-Lajoinie, M-M. (1999). Reconstruire son identité par le récit de vie. Paris : L'Harmattan.

Price, L.L., Arnould E.J. \& Curasi C.F. (2000). Older consumers' disposition of special possessions. Journal of Consumer Research, 27 (2), 179-201.

Relph, E. (1976). Place and placelessness. London: Pion.

Rimé, B. (2005). Le partage social des emotions. Paris : PUF.

Rubinstein, R.I. (2002). Reminiscence, personal meaning, themes, and the "object relations" of older people, In J.D. Webster \& B.K. Haight (Eds.), Critical advances in reminiscence work : From theory to application (pp.153-164). New-York: Springer Publishing Company. 
Satorra, A. \& Bentler, P.M. (1988). Scaling corrections for chi-square statistics in covariance structure analysis. American Statistical Association, Proceedings of the Business and Economic Sections, 308-313.

Schewe, C.D. \& Balazs, A.L. (1992). Role transitions in older adults: A marketing opportunity. Psychology and Marketing, 9 (2), 85-99.

Schoklitsch, A. \& Baumann, U. (2012). Generativity and aging: A promising future research topic?. Journal of Aging Studies, 26 (3), 262-272.

Steenkamp, J-B.E.M. \& Van Trijp, H.C.M. (1991). The use of LISREL in validating marketing construct. International Journal of Research in Marketing, 8 (4), 283-289.

Tarman, V. I. (1988). Autobiography: The negotiation of a lifetime. International Journal of Aging and Human Development, 27 (3), 171-191.

Thompson, C. J. (1996). Caring consumer: gendered consumption meanings and the juggling lifestyle. Journal of Consumer Research, 22, 388-407.

Thompson, C. J. (1997). Interpreting consumers: A hermeneutical framework for deriving marketing insights from the texts of consumers' consumption stories. Journal of Marketing Research, 34, 438-455.

Thompson, C. J. \& Tambyah S.K. (1999). Trying to be cosmopolitan. Journal of Consumer Research, 26 (December), 214-241.

Unruh, D.R. (1983). Death and personal history: Strategies of identity preservation. Social Problems, 30, 340-351.

Urien, B. \& Kilbourne W. (2011). On the role of generativity and self-enhancement values in eco-friendly behavioral intentions and environmentally responsible consumption behavior. Psychology and Marketing, 28 (1), 69-90.

Vaillant, G. E. (2002). Aging well. New-York: Little, Brown and Company.

Wallendorf, M. \& Arnould, E.J. (1988). My favorite things: A cross-cultural inquiry into object attachment, possessiveness, and social linkage. Journal of Consumer Research, 14 (4), 531547.

Wapner, S., Demick, J. \& Redondo, J.P. (1990). Cherished possessions and adaptation of older people to nursing homes. International Journal of Aging and Human Development, 31 (3), 219-236.

Webster, J.D. (1997). The reminiscence functions scale: A replication. International Journal of Aging and Human Development, 44 (2), 137-148.

Webster, J.D. (2003). The reminiscence circumplex and autobiographical memory functions. Memory, 11 (2), 203-215.

Zanone, D. (2006). L'autobiographie. Paris : Ellipses.

Zarca, B. (2009). Triple démarche pour une transformation de soi. Psychanalyse, socio-analyse et autobiographie. Le coq-héron, 198, 118-130. 


\section{APPENDIX. Measurement Instrument}

Table A1. Life-story writing motivations measurement scale

I would like to write my life story $\ldots(1=$ strongly disagree, $5=$ strongly agree $)$

Construct and Item

Cronbach's

Alpha

Agentic motivations

- To talk about the interesting things I have done in my life

- To highlight things I have done and am proud of

- To highlight things about myself that others are not necessarily aware of

- To help me clarify a period in my life

- To tell the truth about certain things that happened in the past

- To justify certain things I did in the past

Family communal motivations

- To tell the younger generation about family members who have died

- To transmit family values

- For the younger members of the family who want to know about their roots

Social communal motivations

- To leave a trace of the way we lived, so that future generations can picture our way of life

- To leave a testimonial, because it is a sort of heritage you pass on to future generations

- To preserve certain aspects of my culture that are disappearing

Table A2. Generativity and Reminiscence measurement scale

$(1=$ strongly disagree, $5=$ strongly agree $)$

Construct and Item

Cronbach's

Passing on Generativity Alpha

- I have important skills that I try to teach others

- I try to pass on the knowledge I gained through my experiences

- I have made and created things that have an impact on other people

Posterity Generativity

- I think that I will be remembered for a long time after I die

- Others would say that I have made unique contributions to society

- I feel as though my contributions will exist after I die

Death preparation reminiscence

- I remember my past because it helps me prepare for my own death

-I remember my past because I feel less fearful of death after I finish reminiscing

-I remember my past because it helps me to cope with thoughts of my own mortality 
Table A3. Writing-behavior measurement scale

$1=$ Not interested, 2 = Interested, but does not plan to write yet, $3=$ Plans to write one day, $4=$ Already involved in the writing process

Construct and Item

Cronbach's

Writing behavior

Alpha

- Are you writing an autobiography?

- Are you writing your memoires?

- Do you keep a "personal" diary

Table A4. Intent to consume biographic services measurement scale

The items are preceded by the phrase "Would you be interested in..." ( 1 = Not at all interested, 4 = very interested)

Construct and Item

Cronbach's

- Writing workshops to learn how to write about memories

Alpha

- Workshops to improve writing style

- A private writer who helps you to write your memoires 